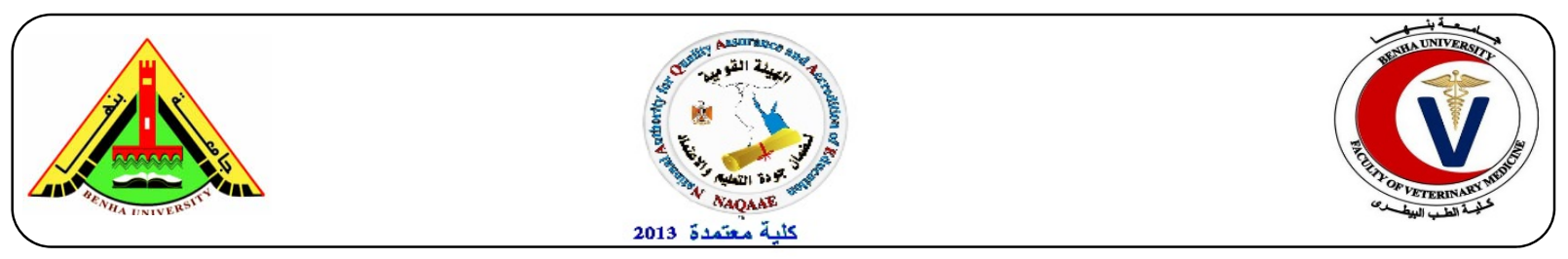

\title{
Effect of some disinfectants on some pathogenic microorganisms isolated from poultry farm
}

\author{
Abdelal, S.A. ${ }^{1}$; Tulip, A. Abdulghaffar' ${ }^{1}$ Halla E.K. El Bahgy ${ }^{1}$; Metawea, Y.F. ${ }^{1}$ and Kamel, M.H. ${ }^{2}$ \\ ${ }^{1}$ Department of Animal Hygiene Behavior and Management, Faculty of Veterinary Medicine, Benha University. ${ }^{2}$ \\ Officer of the armed forces
}

\begin{abstract}
A B S T R A C T
This study was conducted as a field study to select the most effective disinfectants for control of the microbial contamination in poultry farms through evaluation of some commercial disinfectants. All tested commercial disinfectants were diluted with sterile tap water and applied at different concentrations $(0.5$ and $1.0 \%)$ on contaminated surfaces (concrete) by spraying at a rate of $0.5 \mathrm{liter} / \mathrm{m}^{2}$. The Aerobic Plate Count (APC) on naturally contaminated floor of broiler farm was determined before the application of commercial disinfectants at different concentrations with contact times of $15,30,60$, and 120 minutes. The results revealed that disinfectants at concentration of $0.5 \%$ had little action on the tested pathogens as S. Typhimurium, E. coli and S. aureus after 30 and 60, 90 and 120 minutes contact time. While, application of Virudox-G, Glutarol and Alkadox at concentration of $1 \%$ for 120 minutes contact time was efficient and proved $100 \%$ reduction either for of the pathogens count. While, Phenodex showed the lowest inhibitory effect on these pathogens.
\end{abstract}

Key words: Disinfectants, S. Typhimurium, E. coli, S. aureus, Broiler farm

(http://www.bvmj.bu.edu.eg)

(BVMJ-31(1): 154-158, 2016)

\section{INTRODUCTION}

Disinfection process is the inactivation of disease producing microorganisms. However, disinfection does not destroy bacterial spores. Disinfectants are used on inanimate objects and usually involve chemicals, heat or ultraviolet light. The nature of chemical disinfection varies with the type of product used (CDC., 2016). Effective sanitation and disinfection programs are very important to control and reduce such contamination with pathogenic microorganisms in the poultry farm and consequently reduce the human infection with them and produce high quality chicks and increase egg hatchability (Chen et al., 2002). The efficacy of such sanitation programs may be increased through the examination of bacterial contamination of air and the other surfaces inside the poultry house (Brake and Sheldon, 1990). An additional element to prevent introduction and spread of diseases is the use of disinfectants which act on microorganisms at several target sites resulting in membrane disruption, metabolic inhibition and lysis of bacterial cells (Dvorak, 2005; Smith and June, 1999). Actually, disinfectants are important components of bio-security programs.
Disinfectants include several types such as phenolics, aldehyde, quaternary ammonium compounds (QAC), halogens, oxidizing agents, Chlorhexidine compounds, and alcohols (Payne et al., 2005). In the field, there are many factors interfere with the disinfectants activities such as dilution, temperature, time of contact, organic matter (OM), $\mathrm{pH}$, hardness and mode of application as well as type of microorganism (Robison et al., 1988). Usually disinfectants are cidal in that they kill the susceptible potential pathogenic agents. The selection of a disinfectant should be based on the function of the disinfectant expected to perform, not necessary on a sales pitch or on what you have always used. Ideally, a disinfectant should be broad spectrum on a wide range of microorganisms (eliminates bacteria, viruses, protozea, fungi and spores), non-irritating, nontoxic, non-corrosive and inexpensive. Selection decisions should include effectiveness against the potential pathogenic agent, safety to people, impact on equipment, the environment and expense (CDC, 2003). This field study aimed to select the most effective disinfectants to control the microbial contamination in poultry farms through evaluation of some commercial disinfectants. 


\section{MATERIALS AND METHODS}

\subsection{Samples}

The present work applied in two broiler farms located in Qaluobia and Sharqia Governorates, to evaluate the disinfection process as well as to determine the major input of infection into poultry farms.

\subsection{Commercial disinfectants}

The tested disinfectants were Virudox-G, Glutarol, Alkadox, Swift, Iodoline, and Phenodex.

All tested commercial disinfectants were diluted with sterile tap water and applied at different concentrations $(0.5$ and $1.0 \%)$ on contaminated surfaces (concrete) by spraying at a rate of 0.5 liter $/ \mathrm{m} 2$. Theneutralizer of choice was letheen broth for Germicidan F1, and $0.5 \%$ sodium thiosulphate for Virucidal Extra and Germicidan Iodes, according to (Macfaddin, 1976).

\subsection{The Procedures}

The Aerobic Plate Count on naturally contaminated floor of broiler farm was determined before the application of commercial disinfectants at different concentrations. After 15, 30, 60, and 120 minutes of contact times, the viable bacteria per $\mathrm{cm}^{2}$ were picked up by sterile moistened cotton swabs and inserted in tubes of each contained 9 sterile saline plus $1 \mathrm{ml}$ of neutralizer and transported to the lab in an ice box to determine the APC and calculate the percentage (\%) of reduction of microbial count. The procedures were carried out according to (Ahmad and Sotohy, 1998).

\section{RESULTS}

It is evident from the results recorded in table (1) that using of certain disinfectants at concentration of $0.5 \%$ had little action on the tested pathogens S. Typhimurium, E. coli and S. aureus after 30 minutes contact time. Accurately, Virudox-G had the powerful effect $(91.9 \%, 100 \%$ \& 92.7\%), however, Phenodex had the weakest action $(16 \% .60 \% \& 74 \%)$ on viability of $S$. Typhimurium, E. coli and S. aureus, respectively.

After 60 minutes contact time, the reduction of these pathogens became $92.8 \%, 100 \% \& 93.3 \%$ by using Virudox-G and was $30 \%, 77 \%$ and $90.2 \%$ by using Phenodex as shown in table (2). On the other side, the results displayed in table (3) indicated that
Virudox-G and Glutarol at concentration of 0.5 for 90 minutes led to complete destruction of $E$. coli. $S$. aureus was completely killed only by using Virudox-G. On contrast, the applied disinfectants had different action on S. Typhimurium starting from Virudox-G (95.8\%) and ending with Phenodex (70\%).

Moreover, the disinfectant efficacy $(0.5 \%)$ against these pathogens after 120 minutes contacts time was shown in table (4). The reduction percentages by using Virudox-G, Glutarol, Alkadox, Swift, Iodoline and Phenodex were $100 \%$, 99.6\%, 99.4\%, 99.3\%, 99.0\% \& 97.4\% against Typhimurium, respectively. Complete destruction of E. coli was obtained by using of Virudox-G, Glutarol and Alkadox while, Virudox$\mathrm{G}$ and Glutarol had the most destructive action $(100 \%)$ on S. aureus.

The efficacy of the selected disinfectant at concentration of $1 \%$ against $S$. Typhimurium, E. coli and S. aureus after 30 minutes' contact time was shown in table (5). The great effect was obtained by Virudox-G (99.5\%, 100\% \& 100\%) against S. Typhimurium, E. coli and S. aureus followed by Glutarol( $99.7 \%, \quad 100 \% \quad \& 99.4 \%)$, Alkadox $(99.1 \%, 99.9 \%$ \& $99.6 \%)$ and finally by Phenodex (93.9\%, 99.3\% \& 99.6\%), respectively.

The results presented in table (6) revealed that Virudox-G and Glutarol had the most lethal effect on S. Typhimurium, E. coli and S. aureus $(100 \%$ of each) after 60 minutes contact time at concentration of $1 \%$ however; Phenodex had the little action on such pathogens.

The results given in table (7) pointed out that Virudox-G, Glutarol, Alkadox and Swift at concentration of $1 \%$ had $100 \%$ reduction against $E$. coli after 90 minutes contact time. Completed killing of S. aureus was attained by using VirudoxG, Glutarol and Alkadox. Concerning $S$. Typhimurium, the using of Virudox-G and Glutarol resulted in complete reduction $(100 \%)$ in its viability.

Furthermore, the application of Virudox-G, Glutarol and Alkadox at concentration of $1 \%$ for 120 minutes contact time was efficient and proved $100 \%$ reduction either for S. Typhimurium, E. coli or $S$. aureus while, Phenodex showed the lowest inhibitory effect on these pathogens as shown in table (8). 
Effect of some disinfectants on some pathogenic microorganisms

Table 1. Disinfectant efficacy against selected bacteria $\left(1.0 \times 10^{6} / \mathrm{cm}^{2}\right)$ after $30 \mathrm{~min}$ contact time

\begin{tabular}{lllllll}
\hline Pathogen & \multicolumn{2}{l}{ S. Typhimurium } & E. coli & & \multicolumn{2}{l}{ S. aureus } \\
Disinfectant (0.5\%) & Count & Reduction\% & Count & Reduction \% & Count & Reduction \% \\
& & & & & & \\
\hline Virudox-G & $8.1 \times 10^{4}$ & 91.9 & 0 & 100 & $7.3 \times 10^{4}$ & 92.7 \\
Glutarol & $1.5 \times 10^{5}$ & 85.0 & $6.0 \times 10^{4}$ & 94.0 & $9.8 \times 10^{4}$ & 90.2 \\
Alkadox & $2.3 \times 10^{5}$ & 77.0 & $9.1 \times 10^{4}$ & 90.9 & $1.7 \times 10^{5}$ & 83.0 \\
Swift & $2.9 \times 10^{5}$ & 71.0 & $1.4 \times 10^{4}$ & 98.6 & $2.2 \times 10^{5}$ & 78.0 \\
Iodoline & $5.7 \times 10^{5}$ & 43.0 & $2.7 \times 10^{5}$ & 73.0 & $1.9 \times 10^{5}$ & 81.0 \\
Phenodex & $8.4 \times 10^{5}$ & 16.0 & $4.0 \times 10^{5}$ & 60.0 & $3.6 \times 10^{5}$ & 74.0 \\
\hline
\end{tabular}

Table 2. Disinfectant efficacy against selected bacteria $\left(1.0 \times 10^{6} / \mathrm{cm}^{2}\right)$ after 60 min contact time

\begin{tabular}{lllllll}
\hline Pathogen & \multicolumn{2}{l}{ S. Typhimurium } & E. coli & & \multicolumn{2}{c}{ S. aureus } \\
Disinfectant (0.5\%) & Count & Reduction\% & Count & Reduction \% & Count & Reduction \% \\
& & & & & & \\
\hline Virudox-G & $7.2 \times 104$ & 92.8 & 0 & 100 & $6.7 \times 104$ & 93.3 \\
Glutarol & $1.0 \times 105$ & 90.0 & $5.1 \times 104$ & 94.9 & $9.2 \times 104$ & 90.8 \\
Alkadox & $1.9 \times 105$ & 81.0 & $8.6 \times 104$ & 91.4 & $1.3 \times 105$ & 87.0 \\
Swift & $2.6 \times 105$ & 74.0 & $9.0 \times 104$ & 91.0 & $1.5 \times 105$ & 85.0 \\
Iodoline & $4.8 \times 105$ & 52.0 & $2.1 \times 105$ & 79.0 & $5.9 \times 104$ & 94.1 \\
Phenodex & $7.0 \times 105$ & 30.0 & $2.3 \times 105$ & 77.0 & $9.8 \times 104$ & 90.2 \\
\hline
\end{tabular}

Table 3. Disinfectant efficacy against selected bacteria $\left(1.0 \times 10^{6} / \mathrm{cm}^{2}\right)$ after 90 min contact time

\begin{tabular}{lllllll}
\hline Pathogen & \multicolumn{2}{l}{ S. Typhimurium } & \multicolumn{2}{l}{ E. coli } & & \multicolumn{2}{l}{ S. aureus } \\
Disinfectant $(0.5 \%)$ & Count & Reduction\% & Count & Reduction \% & Count & Reduction \% \\
\hline Virudox-G & $4.2 \times 104$ & 95.8 & 0 & 100 & 0 & 100 \\
Glutarol & $7.0 \times 104$ & 93.0 & 0 & 100 & $5.9 \times 104$ & 94.1 \\
Alkadox & $8.3 \times 104$ & 91.7 & $2.8 \times 104$ & 97.2 & $7.4 \times 104$ & 92.6 \\
Swift & $9.9 \times 104$ & 90.1 & $5.6 \times 104$ & 94.4 & $8.1 \times 104$ & 91.9 \\
Iodoline & $1.7 \times 105$ & 83.0 & $7.2 \times 104$ & 92.8 & $6.3 \times 104$ & 93.7 \\
Phenodex & $3.0 \times 105$ & 70.0 & $8.9 \times 104$ & 91.1 & $6.9 \times 104$ & 93.1 \\
\hline
\end{tabular}

Table 4. Disinfectant efficacy against selected bacteria $\left(1.0 \times 10^{6} / \mathrm{cm}^{2}\right)$ after 120 min contact time

\begin{tabular}{lllllll}
\hline Pathogen & \multicolumn{2}{l}{ S. Typhimurium } & E. coli & & \multicolumn{2}{c}{ S. aureus } \\
Disinfectant (0.5\%) & Count & Reduction\% & Count & Reduction \% & Count & Reduction \% \\
& & & & & & \\
\hline Virudox-G & 0 & 100 & 0 & 100 & 0 & 100 \\
Glutarol & $4.1 \times 103$ & 99.6 & 0 & 100 & 0 & 100 \\
Alkadox & $5.8 \times 103$ & 99.4 & 0 & 100 & $1.7 \times 103$ & 99.8 \\
Swift & $8.3 \times 103$ & 99.3 & $6.0 \times 102$ & 99.9 & $3.2 \times 103$ & 99.7 \\
Iodoline & $1.0 \times 104$ & 99.0 & $1.0 \times 103$ & 99.9 & $9.0 \times 102$ & 99.9 \\
Phenodex & $2.6 \times 104$ & 97.4 & $2.2 \times 103$ & 99.8 & $1.1 \times 103$ & 99.9 \\
\hline
\end{tabular}


Table 5. Disinfectant efficacy against selected bacteria $\left(1.0 \times 10^{6} / \mathrm{cm}^{2}\right)$ after $30 \mathrm{~min}$ contact time

\begin{tabular}{lllllll}
\hline Pathogen & \multicolumn{2}{l}{ S. Typhimurium } & E. coli & & \multicolumn{2}{l}{ S. aureus } \\
Disinfectant (1\%) & Count & Reduction\% & Count & Reduction \% & Count & Reduction \% \\
\hline Virudox-G & $5.2 \times 103$ & 99.5 & 0 & 100 & 0 & 100 \\
Glutarol & $6.3 \times 103$ & 99.4 & 0 & 100 & $3.0 \times 103$ & 99.7 \\
Alkadox & $9.5 \times 103$ & 99.1 & $1.0 \times 103$ & 99.9 & $4.1 \times 103$ & 99.6 \\
Swift & $1.8 \times 104$ & 98.2 & $3.2 \times 103$ & 99.7 & $6.5 \times 103$ & 99.3 \\
Iodoline & $3.3 \times 104$ & 96.7 & $5.9 \times 103$ & 99.4 & $2.7 \times 103$ & 99.7 \\
Phenodex & $6.1 \times 104$ & 93.9 & $7.0 \times 103$ & 99.3 & $4.2 \times 103$ & 99.6 \\
\hline
\end{tabular}

Table 6. Disinfectant efficacy against selected bacteria $\left(1.0 \times 10^{6} / \mathrm{cm}^{2}\right)$ after $60 \mathrm{~min}$ contact time

\begin{tabular}{lllllll}
\hline Pathogen & \multicolumn{2}{l}{ S. Typhimurium } & E. coli & & \multicolumn{2}{c}{ S. aureus } \\
Disinfectant (1\%) & Count & Reduction\% & Count & Reduction \% & Count & Reduction \% \\
& & & & & & \\
\hline Virudox-G & 0 & 100 & 0 & 100 & 0 & 100 \\
Glutarol & $4.0 \times 103$ & 99.6 & 0 & 100 & 0 & 100 \\
Alkadox & $4.9 \times 103$ & 99.5 & 0 & 100 & $2.0 \times 103$ & 99.8 \\
Swift & $7.8 \times 103$ & 99.2 & $9.0 \times 102$ & 99.9 & $2.2 \times 103$ & 99.8 \\
Iodoline & $9.0 \times 103$ & 99.1 & $2.3 \times 103$ & 99.8 & $1.0 \times 103$ & 99.9 \\
Phenodex & $1.2 \times 104$ & 98.8 & $3.5 \times 103$ & 99.6 & $1.7 \times 103$ & 99.8 \\
\hline
\end{tabular}

Table 7. Disinfectant efficacy against selected bacteria $\left(1.0 \times 10^{6} / \mathrm{cm}^{2}\right)$ after $90 \mathrm{~min}$ contact time

\begin{tabular}{llllllll}
\hline Pathogen & \multicolumn{2}{l}{ S. Typhimurium } & E. coli & & & \multicolumn{2}{l}{ S. aureus } \\
Disinfectant (1\%) & Count & Reduction\% & Count & & Reduction \% & Count & Reduction \% \\
\hline Virudox-G & 0 & 100 & 0 & 100 & 0 & 100 & 0 \\
Glutarol & 0 & 100 & 0 & 100 & 0 & 100 & 0 \\
Alkadox & $2.6 \times 103$ & 99.7 & 0 & 100 & 0 & 100 & $2.6 \times 103$ \\
Swift & $4.4 \times 103$ & 99.5 & 0 & 100 & $1.4 \times 103$ & 99.8 & $4.4 \times 103$ \\
Iodoline & $5.9 \times 103$ & 99.4 & $9.0 \times 102$ & 99.9 & $5.0 \times 102$ & 99.9 & $5.9 \times 103$ \\
Phenodex & $7.7 \times 103$ & 99.2 & $2.1 \times 103$ & 99.8 & $1.0 \times 103$ & 99.9 & $7.7 \times 103$ \\
\hline
\end{tabular}

Table 8. Disinfectant efficacy against selected bacteria $\left(1.0 \times 10^{6} / \mathrm{cm}^{2}\right)$ after $120 \mathrm{~min}$ contact time

\begin{tabular}{llllllll}
\hline Pathogen & \multicolumn{2}{l}{ S. Typhimurium } & \multicolumn{2}{c}{ E. coli } & & S. aureus \\
Disinfectant (1\%) & Count & Reduction\% & & Count & $\begin{array}{l}\text { Reduction } \\
\%\end{array}$ & Count & Reduction \% \\
\hline Virudox-G & 0 & 100 & 0 & 100 & 0 & 100 & 0 \\
Glutarol & 0 & 100 & 0 & 100 & 0 & 100 & 0 \\
Alkadox & 0 & 100 & 0 & 100 & 0 & 100 & 0 \\
Swift & $6.0 \times 102$ & 99.9 & 0 & 100 & 0 & 100 & $6.0 \times 102$ \\
Iodoline & $1.0 \times 103$ & 99.9 & $4.0 \times 102$ & 99.9 & $3.0 \times 102$ & 99.9 & $1.0 \times 103$ \\
Phenodex & $2.1 \times 103$ & 99.8 & $1.0 \times 103$ & 99.9 & $7.0 \times 102$ & 99.9 & $2.1 \times 103$ \\
\hline
\end{tabular}




\section{DISCUSSION}

Using of certain disinfectants at concentration of $0.5 \%$ had little action on the tested pathogens $S$. Typhimurium, E. coli and S. aureus after 30 and 60, 90 and 120 minutes contact time. Application of Virudox-G, Glutarol and Alkadox at concentration of $1 \%$ for 120 minutes contact time was efficient and proved $100 \%$ reduction either for $S$. Typhimurium, E. coli or S. aureus. While, Phenodex showed the lowest inhibitory effect on these pathogens.

Generally, the efficiency of disinfectants depends on the concentration and exposure time. All disinfectants need a minimum time of $5-10$ minutes to destroy various types of microorganisms in the absence of organic matter (Linton et al., 1987). In this respect, the antimicrobial activity of most disinfectants were reduced to different degrees in the presence of organic matter, while the compounds containing glutraldeyde were the least affected by organic matter (Metawea, 2000 ).Accordingly, removal of organic matter and other interfering substances is a primary consideration before application of disinfectants.

In previous studies, the most effective disinfectants used for reducing bacterial contamination were a product contains glutraldehyde. The other products ranking in order of efficiency on bacteria was iodophorsand combination of quaternary ammonium compounds and formaldehyde (Fate et al., 1985). Also, the efficacy of 2\% glutraldehyde against suspension of microorganisms (Salmonella, S. aureus and E. coli) was effective in 10-20 minutes (Vizcaino-Alcaide et al., 2003).

\section{REFERENCES}

Ahmad, M.M., Sotohy, S.A., 1998. Survival of Salmonella typhimurium and E.coli in poultry environment under different thermal conditions. Assuit Vet. Med. J. 38, $16-28$.

Brake, J., Sheldon, B.W., 1990. Effect of a quaternary ammonium sanitizer for hatching eggs on their contamination, permeability, water loss, and hatchability. Poultry science $69,517-525$.

CDC, 2003. Centre for disease control A guide to selection and use of disinfectants.

CDC., 2016. Centre for disease control Division of oral health- infection control glossary. Retrieved 19 April.

Chen, S.J., Lee, T.E., Wang, E.M., Cho, T.J., Wang, C.H., 2002. Monitoring the hygene of chicken hatcheries in Taiwan during 19992001. Journal of microbiology, immunology, and infection. 35, 236-242.

Dvorak, G., 2005. Disinfection 101.The Center for Food Security and Public Health, Lowa State University.

Fate, M.A., Skeeles, J.K., Whitfill, C.E., Russell, I.D., 1985. Evaluation of four disinfectants under poultry grow-out conditions using contact agar sampling technique. Poultry science 64, 629-633.

Linton, Y., Hugo, W.B., Russel, A.D., 1987. Disinfection In: Veterinary and farm animal practice. 2nd Ed. Oxford London Edinburgh. Black well Scientific Publication.

Macfaddin, J.F., 1976. Biochemical tests for identification medical bacteria. Warery press, INC. Baltimore, Md. 21202 USA.

Metawea, Y.F., 2000 Some epidemiological studies on E.coli in poultry farms. M. V. Sc. Thesis (Hygiene), Fac. Vet. Med. (Moshtohor), Zag. Univ.

Payne, J., Kroger, E., Watkins, S., 2005. Evaluation of disinfectant efficacy when applied to the floor of poultry grow-out Facilities. J. Appl. Poult. Res. 14, 322-329.

Robison, R.A., Bodily, H.L., Robinson, D.F., Christensen, R.P., 1988. A suspension method to determine reuse life of chemical disinfectants during clinical use. Appl. and environ. Microbiol. 54, 158-164.

Smith, T., June, W., 1999. Sanitation, cleaning and disinfectants. Mississippi State University Extension Service, Starkville, MS.

Vizcaino-Alcaide, M.J., Herruzo-Cabrera, R., Fernandez-Acenero, M.J., 2003. Comparison of the disinfectant efficacy of Perasafe and $2 \%$ glutaraldehyde in in vitro tests. The Journal of hospital infection 53, 124-128. 